
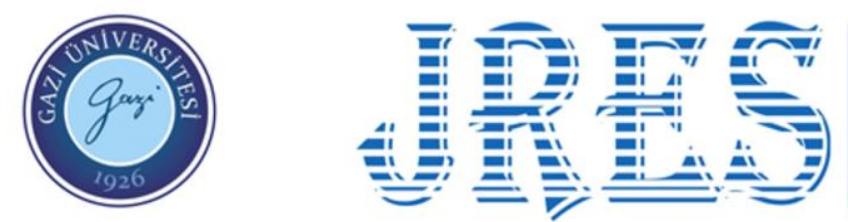

\title{
Toplumsal ve Kültürel Değişimlerin Sanat Eğitimine Yansımaları*
}

\author{
Reflections of Social and Cultural Changes on Art Education
}

\section{Kürşat Azılıoğlu, Meliha Yılmaz}

\section{ÖZ}

Toplumsal ve kültürel alandaki tüm değişimlerin etkileri toplumu oluşturan tüm yapı katmanlarında olduğu gibi sanat alanında da görülebilmekte ve bu değişimler dolayısıyla sanat eğitimini de etkilemektedir. Günümüz sanatı, ele aldığı konular, üretim teknikleri ve ifade olanakları itibarıyla okunması ve anlaşılması daha zor bir alan hâline gelmiştir. Küreselleşmenin etkisindeki postmodernist günümüz sanatı, teknolojik gelişmelerin paralelinde ortaya çıkan yeni iletim ve sunuş yöntemleri açısından medyayı da içinde alan çok disiplinli bir yapıya dönüşmüş ve tüm bu gelişmeleri sanat eğitimi perspektifinden okuyabilmek, anlamlandırabilmek daha güç hâle gelmiştir. Bu süreçte yeni medya, görsel kültür ve medya okuryazarlığı gibi kavramların sanat eğitimine adaptasyonu gerekli hâle gelmiştir. Bu çalışmanın amacı, toplumsal ve kültürel değişimlerin sanata ve sanat eğitimine yansımalarını ortaya koymaktır. Değişimlerin sanat eğitimine yansımaları Türkiye'de sanat eğitimi veren yükseköğretim kurumlarından Güzel Sanatlar Fakülteleri ve Eğitim Fakülteleri Resim- İş Eğitimi Anabilim Dalları ile sınırlandırılmıştır. Bu araştırmada veri toplama tekniği olarak literatür tarama yöntemi kullanılmıştır.
Yazar Bilgileri Kürşat Azılıŏlu iD

Arş. Gör., Gazi Üniversitesi,

Ankara, Türkiye

kursatazilioglu@msn.com

Meliha Yilmaz

Prof. Dr., Gazi Üniversitesi,

Ankara, Türkiye

mel.yilmaz0637@gmail.com

\begin{abstract}
The effects of all changes in the social and cultural fields can be seen in the field of art as well as in all the layers that make up the society, and these changes also affect art education. Today's art has become a more difficult field to read and understand in terms of the subjects it deals with, and production techniques and expression possibilities. Postmodernist contemporary art, under the influence of globalization, has turned into a multi-disciplinary structure that includes the media in terms of new transmission and presentation methods that emerged in parallel with technological developments, and it has become more difficult to read and make sense of all these developments from the perspective of art education. In this process, the adaptation of concepts such as new media, visual culture and media literacy to art education has become necessary. The aim of this study is to reveal the reflections of social and cultural changes on art and art education. The reflections of the changes on art education are limited to Fine Arts Faculties and to Painting Education Departments of Education Faculties, which are among the higher education institutions providing art education in Turkey. In this study, literature review method was used as data collection technique.
\end{abstract}

Makale Bilgileri
Anahtar Kelimeler
Toplum
Kültür
Sanat
Sanat eğitimi
Keywords
Society
Culture
Art
Art education
Makale Geçmişi
Geliş: $09 / 12 / 2021$
Düzeltme: $13 / 12 / 2021$
Kabul: $13 / 12 / 2021$

Makale Bilgileri

Toplum

Kültür

Sanat

Sanat eğitimi

Keywords

ety

Art (1) 


\section{Giriş}

Varlıklarının başlangıcından günümüze değin değişime direnebilen, karşı koyabilen hiçbir toplum var olamamıştır. Toplumsal değişimlerin evreni, vadeleri, kaynağı, hızı, neticesi ve yönü çeşitli iç ve dış etkenlere bağlı olarak değişebilmektedir. Toplumsal değişimleri etkileyen belli başlı unsurlar fiziki-coğrafi etkenler, demografik değişimler, bilim, teknik ve eğitimdeki gelişimler, iktisadi etmenler, din- dünya görüşündeki değişim, sosyal hareketler ve toplumlar sayılabilir (Sunar, 2018, s. 20). "Günümüzde sanatı ve sanat eğitimini kültürel bileşenlerle birlikte düşünmemize katkı sağlayan sosyal, iletişimsel ve teknolojik gerektirmeler söz konusudur." (Eker ve Aslan, 2010, s. 251).

Neredeyse iki yüz elli yıl kadar sürmüş olan ve günümüz toplumsal yapısı üzerindeki etkileri kısmen de olsa hâlen devam etmekte olan endüstri çağından bilgi çağı olarak adlandırılan yeni bir çağa geçilmiştir. Günümüz bilgi çağında toplumsal değişimler genel olarak teknolojik gelişmelerin etkisindeki değişimler olarak öne çıkmaktadır. Teknoloji alanındaki gelişmeler ve değişimler yeni yaşam koşulları ve bunlara bağlı alışkanlıkları beraberinde getirmekte ve tüm bu gelişmeler toplumsal, kültürel yaşamı da etkilemektedir. Enformasyon çağı, dijital çağ gibi adlandırmaları da bulunan bu çağ, tarım ve endüstri çağlarının birçok temel özelliğinden farklılaşmış ve gelişen yeni olanaklar sonucu yeni yaşamsal pratikler üreten elektronik, siber bir çağ olmuştur. Bilgi çağı, toplumsal dönüşümünü insan zihninden ve insanların karşıllklı siber iletişiminden almakta ve temelde insan faktörünün gelişmişliğine bağlı bir toplumsal dönüşüm olarak şekillenmektedir (Meder, 2001, s. 73).

Bilgi çağı, toplumsal sınıfların konumunu ve sermaye gücünün yönünü değiştirmiş topluma gelişen teknolojiye dayalı yeni alışkanlıklar kazandırmıştır. Endüstri çağında toplumun inşasında söz sahibi, belirleyici bir konumu bulunan kentsoylu sınıf günümüzde eskisi kadar güçlü değildir. Tarım toplumunda toprağa ve iklimsel koşullara bağımlı olan birey, günümüz bilgi toplumunda enformatik bir iletim aracına dönüştürülmüş ve toplum bu siber iletinin devamlığı için bireye bağımlı hale gelmiştir. Bilgi çağında küreselleşme olgusu; kültürel ve ekonomik sınırları kaldırmayı amaçlamakta, popüler kültür; insanların zihinlerini, kişisel tercihlerini kapitalist sermaye odaklarının istedikleri gibi yönlendirmek istemektedir. Televizyon, radyo reklamları, sinema ve dizi filmler, sosyal medya platformlarındaki paylaşımlar, gazete, dergi ilanları, billboardlar, panolar, afişler bireyin zihnini görsel ve işitsel bir istilaya maruz bırakmaktadır. Toplum, âdeta tüm kurumları ve bireyleri ile birlikte bu yeniçağa uyum sağlamak mecburiyetinde bırakılmıştır. Bu yeni düzende tüketim kültürünün devamlılığını sağlamak üzere arz-talep ilişkisine ihtiyaç vardır. Medya, yayınları aracılığı ile bireyi tüketmeye yönlendirmektedir. Artık gelişen enformasyon teknolojileri sayesinde "bilgi" insanların ellerinden düşürmedikleri akıllı telefonlar, taşınabilir bilgisayarlar aracıllğı ile anlık olarak iletilebilmekte ve toplumları yönlendirmekte geçmiş dönemlere göre daha da etkili olabilmektedir. Bu dijital dönüşüm toplumun tüm alanlarında olduğu gibi sanat ve toplum ilişkisini de etkilemiştir.

Yaşadığı toplumun bir bireyi olan sanatçısı tarafından, üretildiği toplumun köklerinden beslenerek ortaya çıkan ve toplumun tüm yapı katmanlarıyla ilişkili olan sanat kavramı, filizlendiği toplumun ve kültürün adeta bir aynası gibidir. Sanat, toplumun ve kültürün bilimsel metinlerde rastlanılamayacak kadar gerçek, salt ve aynı zamanda tarihsel bir yönü de olan bir görünümünü sunar. Sanatçı, toplumun bir bireyi, bir parçası olarak üretimlerinin tüm aşamalarında bilinçli ya da bilinçdışı olarak toplumsal bir katkı ile hareket etmektedir. Üretimlerindeki yadsınamaz toplumsal katkı açık veya gizil bir biçimde sanatçının ortaya koyduğu eserde ve sunuş yöntemlerinde görülebilmektedir. Bu yönüyle bir toplumun sanatını incelemek, kültürünü doğrudan anlayabilmenin en doğru yollarından biridir. Bu özelliği ile sanat aynı zamanda sosyolojik ve daha özelde etnolojik bir bilgi kaynağıdır. 
Günümüz sanatı, zaman mefhumunun da ötesinde modern olan ile post- modern, biçimsel olan ile içeriksel olan, soyut olan ile somut, estetik olan ile kitsch gibi zıt kimlik tanımlamalarının tümüne eş zamanlı ve eşit büyüklükte yaşam alanı sağlayan, çok disiplinli ve çok kimlikli bir bünyededir (Oğuz, 2015, s. 78).

"Sanat ve toplum arasındaki ilişki, herhangi bir topluma ait sosyolojik bir verinin doğruluğunu temin edecek ve aynı zamanda kısmi de olsa test edecek tamamlayıcı bir potansiyele sahip olmasından dolayı önemlidir." (Çağan, 2006, s. 14). Adorno'ya (2004) göre “Tıpkı bilgi gibi sanat da malzemesini ve eninde sonunda biçimlerini de gerçeklikten, daha doğrusu toplumsal gerçeklikten alır." (s. 154). Sanat, sanatçısının bir bireyi olduğu toplumun tüm yapı taşlarından beslenerek ortaya çıkar. Sanat ve toplum ilişkisi bu bağlamda toplumsal ve kültürel değişimlerin bir yansıması, bir gölgesi gibidir. “Kültür varlığı ile insan arasındaki karşılıklı ilişki, doğrudan değil eğitim süreciyle kurulur. İnsan ve kültür birbirini daima eğitim süreciyle etkiler ve değiştirir.” (Güvenç, 2016, s. 212).

Sanat eğitimi kavramı yaygın ve tümel anlamında kullanıldığı özellikle belirtilmediği sürece bu makalede de konu olduğu üzere plastik sanatlar alanında verilen eğitimi ifade etmektedir. Sanat eğitimi, toplumun kültürel yapısının inşası ve devamı için hayati önem taşıyan bir olgudur. Sanat eğitimi toplumların geleceğini inşa edecek olan genç bireylerinin güzeli aramalarının, ussal düşüncelerinin şekillenmesinin ve sanat yoluyla iç dünyalarını dışa vurmalarının anahtarıdır. Toplumların kendi kimliklerini ortaya koymada, toplumların geçmişten gelen birikimlerini sonraki kuşaklara aktarmalarında sanat eğitimi sanat yoluyla felsefi boyutları da bulunan görsel bir bilgi kaynağı oluşturur. Kırışoğlu'na (2009) göre, “Sanat eğitiminde yeni görüşler pek çok etkene bağlı olarak ortaya çıkmıştır. Toplumsal ve kültürel değişimler bu etkenlerin başında gelmektedir. Görsel kültürün hızla toplumları etkisi altına alması, düşünsel alanda yaşanan, kültüre ve sanata yansıyan postmodern anlayış ve söylemler, ekonomik anlamda üretimden tüketime kayan ekonomik yapı ve bütün bunların toplumları etkilemesi değişimi zorunlu kılan etmenlerdir" (s. 35). Toplumsal ve kültürel değişimlerin sanat eğitimine etkileri iki boyutludur; birinci boyut toplumsal ve kültürel gelişmelerin etkisinde sanatsal alanda yaşanan değişimlerin dolaylı olarak sanat eğitimini etkilemesi ve ikinci boyut ülkelerin yönetimsel tutumlarının bir sonucu olarak şekillenen eğitim politikalarındaki sanat eğitimine olan bakış açısının sanat eğitiminin amaçlarını ve yönünü belirlemesidir (Kırışoğlu, 2005, s. 13).

\section{Araştırmanın Amacı}

Bu çalışmanın amacı, toplumların ekonomik, kültürel, bilimsel ve teknolojik gelişmelerinin etkisinde küçük-büyük ölçekli toplumsal ve kültürel değişimlerinin sanata ve sanat eğitimine yansımalarını, etkilerini belirlemektir. Sanat, evrensel etkileşimin ve dolayısıyla değişim olgusunun en açık olduğu alt kültürel bileşenlerden biri olduğu için küresel etkileri de olan sanatsal hareketlerin ülkelerin yerel sanat ortamlarına yansımaları da yadsınamaz bir gerçektir. Çok bileşenli gerekçeleri ve sonuçları olan toplumsal ve kültürel değişimler sanatı ve dolayısıyla sanat eğitimini de etkilemektedir. $\mathrm{Bu}$ araştırmada ülkemizdeki toplumsal ve kültürel değişimlerin sanat eğitimine yansımaları ele alınmıştır. Bu amaçla ilgili alanyazın taranmış ülkemizdeki sanat ve sanat eğitiminin Batı ülkeleri kaynaklı olmasından ötürü Batı sanatındaki ve sanat eğitimindeki gelişmelere ve değişimlere de kısaca değinilerek bu değişimlerin ülkemizdeki yansımaları ülkemizdeki değişim dinamiklerinin etkileri ile birlikte yorumlanarak analiz edilmeye çalışılmıştır. 


\section{Yöntem}

$\mathrm{Bu}$ çalışma ilgili literatürün taranması sonucunda oluşturulan teorik bir çalışmadır. $\mathrm{Bu}$ çalışmada veri toplama tekniği olarak literatür tarama yöntemi kullanılmıştır. Literatür tarama çalışmaları; araştırmacılar tarafından önceden tamamlanmış ve kayıt altına alınmış tanımlanmış, değerlendirilmiş ve sentezi yapılmış sistemli, açık ve üretilebilir bir yöntemin kullanıldığı çalışmalardır (Fink, 2009). Araştırmacılar tarafından ilgili literatür taranmış ve analiz edilerek toplumsal ve kültürel değişimlerin Türkiye'deki sanat eğitimine yansımaları belirlenmeye çalışılmıştır.

\section{Etik Bildirim}

Bu makale, derleme türünde olduğu için etik kurul kararı gerektirmemektedir.

\section{Toplum ve Kültür Ekseninde Değişim Olgusu}

"Toplum; yaşamlarını sürdürebilmek, birçok temel çıkarlarını gerçekleştirmek için iş birliği yapan, aynı toprak parçası üzerinde birlikte yaşayan ve ortak bir ekini olan insan kümesi" olarak tanımlanmaktadır (Ozankaya, 1984, s. 115). Güvenç'e (2013) göre "Kültürel" kavramı, "toplumsal" kavramını da içine alacak şekilde anlaşılmalıdır. Aynı zamanda "toplumsal" olgu ve "kültürel" olgu kavramlarını birbirlerinden ayırmak her zaman kolay ya da işlevsel değildir (s. 351). Davis'e (1950) göre “Toplumsal değişim toplumun tüm öğelerinde belirli bir düzeyde değişim gerçekleşmesini sağlayan kültürel değişmenin bir alt düzeyine tekabül etmektedir." (Davis'den aktaran Sunar, 2018, s. 4). Sosyal bilimcilerin büyük çoğunluğu toplumu oluşturan çeşitli kümelere ve kümeler arasındaki ilişkileri "toplumsal" sıfatını kullanarak dile getirmekte başka bir bölümü de "kültür" kavramını toplum hayatının yalnızca küme ilişkileriyle anlatılamayan bölümü olarak açıklamaktadır (Güvenç, 2013, s. 351). Yeryüzünde birçok toplum vardır ve toplumları diğer toplumlardan ayıran en belirgin özellikleri dilleri, dinleri ve kültürleridir. Kültür, bir toplumun bireyi olarak insanoğlunun varlı̆̆ının başlangıcından günümüze kadar geçen süre zarfında deneyimleyerek öğrendiği, kazandığı bilgi, sanat, gelenek-görenek ve benzeri yetenek, beceri ve alışkanlıkları içine alan karmaşık bir bütündür (Tylor'dan aktaran Güvenç, 2018, s. 129). Kültürel değişimlerin ana sebeplerinden biri de kültürel etkileşimlerdir. Bir kültür unsurunun başka birisi tarafından alınmasında ve yayılmasında etkili olan en önemli faktör, fayda teminidir. Bu sebeple fayda temini gözetilmeden değerleri değiştirmeye yönelen modernleşme girişimleri toplumlar tarafından kabul görmemiştir (Turhan, 2015, s. 59-60).

Williams' a göre kültür kelimesin yüz altmış dört farklı tanımı vardır ve tanımlanması en güç kavramlardan biridir. Bunun nedeni de kelimenin birbirinden ayrılan farklı düşünce sistemlerinde ve entelektüel birçok disiplin alanında önemli kavramlar için kullanılmaya başlanmasıdır (Williams, 1977, s. 76-77). Bu makaleye de konu olan kullanımıyla kültür; "çeşitli insan topluluklarının düşünce ve değer birliliklerini meydana getiren tüm üretim ve varlıkları olarak tanımlanmaktadır " (Özlem, 2000, s. 143). “Toplumsal yapı kavramı ise kısaca toplumsal yapılanmanın oluşumunu ortaya koyan özellikler demektir. Fark edilebilecek kadar benzer uygulamaların değişen zaman ve mekânlarda, devam etmesini mümkün kılar ve onlara sistemli şekil görüntüsü verir. Yapı, toplumsal sistemlerin yeniden üretilmesinde etkin rol oynayan kurallar ve kaynaklardır." (Giddens'den aktaran Wallace ve Wolf, 2012, s. 257). Toplumların kültürel yapılarını etkileyen, değişmesine neden olan tarihsel, politik, ideolojik, ekonomik, bilimsel ve teknolojik birçok unsur vardır. Kısaca belirtmek gerekirse toplumsal değişme ; "toplumsal yapının, kurumların, toplumsal ilişkiler ağının, davranış kalıplarının, toplumsal norm ve değerlerin zaman içinde geçirdiği dönüşümler olarak açıklanabilir." (Yeşildal, 2012, s. 55). 
Toplumsal değişmeyi makro düzeyde ele alarak bir tanım geliştiren Tan'a (1981) göre toplumsal değişme; "toplumsal ilişkilerde, kurumlarda ve yapıda belirli bir durumdan ya da varlık biçiminden başka bir durum ya da biçime geçiş" olarak açıklanmaktadır (s. 102). Değişimi mikro düzeyde ele alarak bir tanımlayan Tezcan'a (1998) göre ise "Toplumsal yapının ve onu oluşturan toplumsal ilişkiler ağının ve bu ilişkileri belirleyen toplumsal kurumların değişmesidir." (s. 191). Toplumsal değişim kavramı etrafında oluşan soru işaretlerinden en önemlisi hangi ölçüye kadar ve ne tür değişimlerin toplumsal değişme olarak adlandırılması gerektiğidir (Strasser ve Randall, 1981, s. 11). Küçük bir gruptaki değişimler grubun kendisi için önemli görülebilir fakat daha büyük bir grupta aynı değişim önemsiz ve küçük bir değişme olarak algılanabilir. Değişimin evreni veya vadesi hangi boyuttaki değişimlerin toplumsal olarak adlandırılacağı problemi ile yakından ilişkilidir (Sunar, 2018, s. 2-3). Toplumsal değişimleri miktarları, zaman boyutu ve değişen birimin etkisine göre sınıflandırmak mümkündür (Appelbaum'dan aktaran Sunar, 2018, s. 3).

Değişim kavramı etrafında oluşan sorunsallardan biri de değişimin yönü hakkındadır. Değişimlerin ilerleme mi gerileme mi olarak algılanması gerektiği hususu öznel bir değerlendirme olarak görülmektedir. Strasser ve Randall'a göre değişimin yönü incelemeyi gerçekleştiren araştırmacıların bilişsel ilgilerine bağlıdır (Strasser ve Radall, 1981, s.18). Toplumların yapı taşları olan bireyler, çeşitli değişkenlerin de etkisiyle düşünce ve yaşayış biçimlerinde farklı yönelimlere girebilmekte ve bu değişiklikler kitlesel olarak toplumların genel yönelimlerini de etkileyebilmektedir. Tarihsel, politik, ideolojik, teknolojik gelişimler ve değişimler toplumsal sosyolojik yapıyı da etkilemekte ve bu değişimler sonucu toplumların kültürel yapısı da kaçınılmaz olarak etkilenmektedir. Sosyolojinin ana konularından biri olan toplumsal değişim Belting'e (2020) göre "toplumsal ve kültürel değişimler, kültür politikaları ve küreselleşme karşısında kendi içinde bir mantığa sahip olan, her dönemin stili ve dönüşümleri üzerinden betimlenen yön verici bir sanat tarihi kılavuz imgesi günümüzde varlığını yitirmiştir." (s. 27). Sanat, özellikle plastik sanatlar olarak sınıflanan sanat dalları köklerinden beslendiği toplumun kültürel dinamiklerinin dönüşümsel izlerini kendi içyapısında uzun yıllar barındırır ve sunar. "Hiçbir insan faaliyeti plastik sanatlar kadar kalıcı değildir ve geçmişten günümüze ulaşan başka hiçbir şey, insanlık tarihi için bu kadar değerli bir ipucu sunmamaktadır. İnsanlığın geleneklerine ve inançlarına dair bilgimiz, binlerce yıl öncesinden günümüze ulaşabilen sanat eserlerinden kaynaklanmaktadır; yazılı kayıtların imdadımıza yetişmesi, dünya tarihi içerisinde nispeten yakın zamanlarda gerçekleşmiştir." (Read, 2018, s. 20).

"Toplumsal değişme, devinimsel yargıları içerisinde barındıran iletişimsel temelli bir kavramdır. Toplumsal değişme; ilişkilerin ve ilişkilere bağlı yargıların değişmesidir." (Ergun, 1984, s. 99). Toplumsal yapıdaki farklı grupların birbirinden ayrılan kültürel yapıları da vardır. Bunlar alt kültür, karşı kültür, kitle kültürü, halk kültürü, yüksel kültür ve popüler kültürdür. Tüm bu kültürel çeşitlilik küresel kültür, kültür endüstrisi, popüler kültür, demografik değişim gibi kavramların da eklenmesiyle toplumların kültürel değişimlerini çok hızlı etkileyebilmektedir. Folklorik bir çalışma konusu da olan halk kültürlerinin yaşatılması ve sonraki nesillere aktarılması kültürel çeşitliliğin devamı açısından oldukça önemlidir.

Kültürel alan tanımı ise toplumlara geçmiş kuşaklarından çeşitli yollarla aktarılan tüm değer, kurallar, düşünce yapısı, dünya görüşü ve davranış kalıplarını içeren bir tanımı kapsar. Toplumların, teknolojik değişimlerinden kültürel değişimlerine uzanan yolda, ekonomik, sosyal ve politik unsurlar daha hızlı değişirken, kültür normlarından kolay kolay vazgeçilemez. İşte bu durum, kültürel gecikmenin nedenleri arasındadır (Erkan'dan aktaran Kocacık, 2003, s. 8). Bazı toplumların kültürel anlamda daha gelişmiş olmaları bir anlamda bilim ve felsefenin ışığında ilerlemeleri ve geleneksel 
yargıları çabuk terk edebilme yeteneklerinden kaynaklanmaktadır. Giddens'a göre “Modernlik, ilk aşamalarında gelenek ile çatışır ve onu yok eder; ama sonradan yeniden inşa eder. Gelenek, toplumsal hayatın hemen hemen hiç dokunulmamış olan aile ve cinsel kimlik gibi bazı temel görünüşlerini korumuştur. Ancak, bu durum gelinen noktada değişime uğramıştır. Kısmen dünya çapında modern kurumların çoğalması ve böylece modernleşme sürecinin çok yaygınlaşması, kısmen de olsa geleneklerin meşruluğunu ortadan kaldıran iç değişimler nedeniyle toplumların gelenekleri unutturulmuş bir bakıma ortadan kaldırılmış ve yeniden inşa edilmemiştir." (Giddens'den aktaran Wallace ve Wolf, 2012, s. 260).

“Günümüzde toplumların ve halkların yerel kültürleri devlet kurumlarının ya da özel kuruluşların özel çabalarıyla yaşatılmaya çalışılmaktadır. Günümüzde toplumlar atalarından kendilerine miras kalan kendilerine ait, kendilerine özgü bir kültürü her geçen gün daha az üretmekte ama başka kültürleri kopyalamak, yeniden üretmek için gitgide daha iyi teknikler geliştirmektedir. Eğitimle birlikte, zorunlu kültürel uygulamalara gösterilen sabır da ortadan kalkmakta; kültür, eğitici olmak yerine eğlendirmesi beklenilen bir kavrama dönüştürülmek istenmektedir." (Belting, 2020, s. 31).

Kültürel değişim ona bağlı kurumların ve sistemin tamamında hemen gerçekleşmez. Sistemin belli bir kesimindeki değişimler, geri kalan kurumları da bu yeni duruma uyum sağlamaya zorlamaktadır. Bazı durumlarda değişimin hızına ayak uyduramayan kurumlar değişmeyi yavaşlatmaya; bazı durumlarda ise destekleyip hızlandırmaya çalışır. Fakat her kültürel değişme olayında kurumlar arasında değişim odaklı bir farklılaşma mutlaka ortaya çıkacaktır (Güvenç, 2013, s. 133).

Toplumların kültürel yapılarının değişmesinin en önemli nedenleri arasında küreselleşme gelmektedir. Küreselleşme kavramı, en basit anlamda, "Yerkürenin farklı bölgelerinde yaşayan insan, toplum ve devletlerarasındaki iletişim ve etkileşim derecesinin karşılıklı bağımlılık kavramı çerçevesinde giderek artması olarak tanımlanabilir." (Bayar, 2008, s. 25). Küreselleşmenin beslendiği teknolojik ve siyasal olmak üzere iki ayrı kaynak vardır. Gelişen telefonlar ve bilgisayarlar teknolojik kaynağın iki önemli nedenidir ve bu "iletişim ve bilişim devrimini" doğurmuştur (Kongar, 2001, s. 19). Küreselleşmenin ekonomik, siyasi, teknolojik, çevresel ve kültürel etkileri vardır. Küreselleşme olgusu en çok kültürel alanda etkisini göstermektedir. Küresel kültürün en etkili yayılma araçlarından biri olan uluslararası telekomünasyon ağı aracıllğgı ile küreselleşmenin çıkar odaklarına hizmet eden görsel ve işitsel iletiler tüm yaşam alanlarında bireyin karşısına çıkmakta ve doğrudan ya da dolaylı yoldan bireyi ve toplumu etkileyebilmektedir. Toplumların kültürel değişimlerinin bir başka nedeni de demografik değişimdir. Demografik değişimlerin nedenleri iç ve dış göçlerdir. Toplumların kültürel değişim süreçlerinde en çok etkili olan etkenlerden biri hatta çeşitli kültürlerin karışımından yeni kültürler doğmasına neden olan ana güçlerden birisi göçtür (Brettell ve Hollifield, 2000, s. 4). Gerek yurt içi gerekse yurt dışı kaynaklı göçler kültürel etkileşimi yaratır ve toplum kendisine göre yararlı olanları benimseyerek alır. Toplumların kültürel değişim hızları bu nedenle yavaştır ve yeniyi kabul etmek, yaşamlarına aktarmak her zaman her toplumda münkün olamamaktadır (Sunar, 2018).

Yüzyıllardır değişmeyen tek şey değişimin kaçınılmaz bir şekilde gerçekleşmesi ve toplumsal ve kültürel alanda da oldukça hızlı sonuçlar yaratmasıdır. Kültürlerin birçok bileşeninden biri olan sanat alanları da doğrudan veya dolaylı bir şekilde bu değişimlerden şüphesiz etkilenmektedir.

\section{Türkiye'de Toplumsal ve Kültürel Değişimlere Genel Bakış}

Türk sosyal bilim evreninde toplumsal değişim kavramı genellikle kalkınma hamleleri eksenindeki modernleşme çabaları bağlamında ele alınmıştır (Sunar, 2019, s. 39). Modernleşme 
kuramının önemli isimlerinden biri olan Parsons'a (1960) göre asıl toplumsal değişim, gelenekselden moderne yani eskiden yeniye bir geçişle alakalıdır (Parsons'dan aktaran, Sunar, 2019, s. 39).

Türkiye' de değişim olgusu ağırlıkla siyasi değişimler merkezlidir. Siyasal alandaki değişim toplumları ve kültürlerini doğrudan etkileyen en temel faktörlerden biridir. Dolayısıyla Türkiye'de değişim kavramı çerçevesinde yapılan çalışmalar genel olarak siyasal merkezli çalışmalar olmuştur. Türkiye'deki Milli Mücadele sonrasında kurulan Cumhuriyet'in ilanı da yönetimsel anlamda siyasal bir değişimdir (Akın ve Buçukçu, 2019, s. 93). Cumhuriyet'in ilanı ile başlayan çağdaşlaşma ve kalkınma hamleleri Cumhuriyet'in ilk yıllarından itibaren toplumsal ve kültürel yaşamda önemli kazanımlara ve değişimlere yol açmıştır.

1923 yılında nüfusun neredeyse tamamına yakınının kırsal alanlarda yaşadığı, tarım ve hayvancılık sektörlerinde istihdam edildiği sosyal ve ekonomik yapıdan şehirlere yerleşen, hizmet ve sanayi sektörlerinde çalışmaya başlayan kesimin hızla arttığı yeni bir sosyal yapıya dönüşüm gerçekleşmiştir. Bulutay'a (1995) göre 1924 yılında toplumun \%89,8 'i tarım, \%4,6'sı sanayi ve \% 5,5'i hizmet sektöründe çalışırken 1980 yılına gelindiğinde \% 54,2'lik kesim tarım, \% 20,0 oranında sanayi ve \% 25,8' lik bir kesim hizmet sektöründe çalışmaya başlamıştır. Bu oranlara göre 1960'lı yıllar itibarıyla köylerden kentlere göç başlamış ve göç eden köylü-çiftçi kesim kentlerde ağırlıklı olarak hizmet sektöründe istihdam edilmiştir (Bulutay'dan aktaran Kaya, 2019, s. 77). Bu doksan yılı aşkın süreç boyunca kalkınma ve sanayileşme stratejileri izleyen Türkiye, yaşadığı tüm ekonomik ve politik çalkantılara rağmen günümüzde belli bir oranda sanayileşmesini tamamlamış, orta zenginlikteki gelişmekte olan ülkeler arasındaki yerini alabilmiştir (Kaya, 2019, s. 91). 1970'li yıllarda Türkiye'de küçük-orta ölçekli montaj ve parça üretimleri yapan sanayi tesisleri ortaya çıkmaya başlamıştır. Buna rağmen ağır sanayii hamlelerini gerçekleştirmek bu ve takip eden yıllarda çok hızlı ve başarılı olamamıştır.

Cumhuriyet'in kuruluşundan hatta Osmanlı Devleti'nin son günlerinden başlanarak ülke ekonomisinin, toplumun ve kültürel hayatın ciddi değişimler geçirdiği ve günümüz Türkiye'sinin toplumsal yapısını belirleme açısından en önemli dönem 1980 ve sonrası liberalleşme dönemi olarak ifade edilebilir (Kaya, 2019, s. 75). Ülkenin içinde bulunduğu karışık siyasal atmosfer, toplumsal olaylar, ekonomik problemler ülkenin toplumsal ve kültürel yapısını da etkilemiştir. Kültürel anlamda bu yıllarda "sanatta ulusallık ve evrensellik" tartışmalarının yoğunlaştı̆̆ı gözlemlenmektedir (Yardımcı, 1999, s. 56).

1980 sonrası değişim hareketlerinin hızlanmasında küresel ekonomiye entegrasyon ve liberalleşmenin hız kazanması önemli görülmektedir (Kaya, 2019, s. 89). Toplumsal yapıdaki büyük ölçekli değişimlerin kültürel etkileri de 1980'li yıllar itibarıyla daha net görülebilmektedir. Bu yıllarda eğitim reformlarına rağmen okur- yazarlık oranı düşüktür. Köylerden kentlere kitleler hâlinde göç eden insanlar şehirlerde gece kondu mahalleleri kurmuşlar ve yeni yeni kurulmaya başlayan fabrikalarda ya da hizmet sektöründe çalışmaya başlamışlardır. Bu yıllarda toplum, televizyonun da neredeyse her haneye girmeye başlamışıyla dizi ve sinema filmleri aracılığıyla gelişmiş modern toplumların yaşam biçimlerini, kültürlerini örnek almaya başlamışlardır. Yine 80'li yılların sonlarına doğru ilk özel televizyon kanalı 1987 yılında önce uydu yayını ile ardından 1990 yılında karasal yayın ile hayatımıza girmeye başlamıştır (Özsoy, 201, s. 120). Televizyon bu yıllarda kültürel etkileşimi hızlandıran bir kitle iletişim aracı olmuştur. Televizyonun radyodan farklı olarak hem görsel, hem de işitsel iletim imkânın olması halk tarafından daha çabuk benimsenmesinde ve kültürel etkileşimin daha etkili olmasını 
sağlamıştır. Aynı yıllarda televizyonun daha makul seviyede erişilir olması sayesinde yaygınlaşması sonucu toplumlar üzerinde etkili bir eğitim ve propaganda aracına dönüşmüştür (Oskay, 1971, s. 50).

80'lerden itibaren dünyada uygulanan neoliberal politikalara paralel olarak Türkiye' de 24 Ocak 1980 kararları hayata geçirilmiştir. Böylece devletin ekonomik ve gündelik hayattaki istihdam sağlama politikasından uzaklaştığı görülmektedir (Yıldırım, 2019, s. 234). Devletin, halkına istihdam yaratma gayretini özel sektöre devretmesi ve ekonomik hayattaki devlet tekelinin yavaş yavaş azalmaya başlaması ile toplumsal ve kültürel anlamda değişimler de yaşanmıştır. 1990'lı yıllara gelindiğinde ise liberalleşme hareketlerinin daha reel olarak gözlemlenebildiği ve özelleştirmelerin yaşandığ1 görülmektedir. Özel televizyon ve radyo kanallarının sayıları yavaş yavaş artmaya başlamış kültürel etkileri de olan çok seslilik anlamında önemli bir değişim yaşanmaya başlanmıştır. Yazılı basın bu yıllarda görselliğe daha fazla yer ayırmaya başlamış ve görselliğin ön planda olduğu afişler, ilanlar şehirlerin meydanlarına sokaklarına yerleştirilen billboardlar aracılığı ile yaşam alanlarında daha fazla yer bulmaya başlamışır.

Tüketim toplumu olarak adlandırılan toplum yapısının ülkemizde bu yıllarda oluşmaya başladığı söylenilebilir. Başta İstanbul ve Ankara gibi büyük kentlerde AVM'lerin açılması, çok uluslu hazır giyim ve fast-food zincirlerinin hızla çoğalması, halkın televizyon, radyo, gazete ve dergi reklamları aracılı̆̆ı ile popüler olanı tüketmeye yönlendirilmesi bu yıllarda hız kazanmıştır. Tüketim toplumu terimi, "toplumların maddi üretimden ve hizmet üretiminden ziyade, malların ve boş zamanın tüketimi çerçevesinde tüketim etrafında örgütlenmesini ifade eden bir terimdir." (Marshall' dan aktaran Bayhan, 2011, s. 223). Türkiye de bu yıllarda artan iç ve dış talep ile birlikte turizm sektörü de önemli bir dönüşümü de yaşayarak doğrudan ve dolaylı, dönemsel bir istihdam katkısı sunmaya başlamıştır.

Türk kültür yapısının önemli bir yapı taşı olan aile kavramı özellikle 90'lı yılların sonlarına doğru geleneksel yapısından koparak çekirdek aile yapısına dönüşmüştür. Ekonomik nedenleri ön planda olan zorlu yaşam koşullarının da etkisiyle aile ve birey toplum içinde yalnızlaşmaya başlamıştır. Sosyal dayanışmanın, yardımlaşmanın ön planda olduğu komşuluk bağları ve mahalle kültürü bu yıllarda yok olmaya başlamıştır.

Tüm bu değişimler sanatı ve sanatsal üretimlerin kaynağı olan sanatçıları da gerek sosyolojik gerek psikolojik anlamda çevrelemekte ve dolaylı ya da doğrudan etkilemektedir. Toplumun yaşadığı tüm sevinçler ve üzüntüler sanatçıların üretim aşamalarında etkilendikleri çevreyi ve ifade biçimlerini etkilemektedir. Milenyum adı verilen 2000'li yıllarda sanatçıların eserlerinde konu seçimlerinin daha çok çeşitlendiği üretim ve sunuş yöntemlerinde teknolojinin daha fazla yer aldığı gözlemlenmektedir.

\section{Türkiye'de Cumhuriyet Dönemi Kültür Politikaları}

İnsan Hakları Evrensel Beyannamesinin (IHHEB) 27. Maddesine göre, toplumu oluşturan bireylerin kültürden ortak paydada yararlanması devletlerin kültür politikalarının bir gereği olarak tanımlanmalıdır. Buna göre "Herkes, topluluğun kültürel yaşamına özgürce katılma, sanattan yararlanma ve bilimsel gelişmeye katılarak onun yararlarını paylaşma hakkına sahiptir." (Birleşmiş Milletler İnsan Hakları Komisyonu, 1949).

Kültürler hiçbir zaman kendiliğinden oluşmazlar ve birbirleriyle etkileşim içindedirler. Türk kültürü hem Doğu kültürlerinden hem Batı kültürlerinden aldığı ayrı öğeler içermektedir. Bu nedenledir ki kendi içinde bir bütünlükten, bir sistematikten yoksundur (Çeçen, 1996, s. 27). Bu anlamda Batı uygarlığının kendi içinde daha tutarlı, sistemli ve sürdürülebilir bir kültür politikasının olduğu söylenilebilir. Türkiye'de Cumhuriyetin ilk yıllarından itibaren düzenli olarak her hükümet 
programında kültür politikaları yer almıştır. Her hükemet döneminde farklı bir kültür politikası izlenildiği ve bu politikaların toplum nezdinde kısa ve uzun vadeli fayda teminlerin söz konusu olduğu bilinmektedir. Yeni kurulan Türkiye Cumhuriyeti'nde eğitim öncelikli öneme sahip bir konudur. Cumhuriyet dönemi kültür politikasında yaratıcı insan yetiştirmek bir gereksinim olarak görülmüştür. Bu dönemde sanat; sonsuz deneyime, düşünmeye, tasarıma, anlatıma ve yaratmaya olanak vermesi yönleri ile gelişmede ve ülke kalkınmasında etkili bir araç olarak görülmüştür. 1950'li yıllara kadar olan süreçteki dönemin önemli kazanımlarının başlıca dayanağı kişiler ve kurumlar arasındaki birliğin ve uyumun olmasıdır. Atatürk'ün isteği üzerine ülkemize davet edilen yabancı uzmanların raporları doğrultusunda etkin bir yol haritası çizilmiştir (Kırışoğlu, 2009, s. 20).

Türkiye' de kültür politikaları Cumhuriyet'in ilk yıllardan başlanarak uygar ve aydın bir Türk toplumu yaratma ülküsü doğrultusunda şekillenmiştir. Erken Cumhuriyet dönemi kültür politikaları arasında sanatta ulusallık arayışları da oldukça önemli bir yer tutar. Buna göre sanat yapıtının özgün olması, çağının güncelliğini taşıması, kalıcılığı ve temsil gücü göz önünde bulundurulmuş, buna göre bir yandan sanatçıların yapıtlarının ulusal kimliğini koruması, bir yandan da evrensel olanı yakalaması beklenilmiştir (Bek, 2008, s.17). Türkiye Cumhuriyeti'nin kurucusu büyük önder Gazi Mustafa Kemal Atatürk "Türkiye Cumhuriyeti'nin temeli kültürdür" sözü devletin o yıllardaki kültür politikasını da özetler niteliktedir. Cumhuriyet'in ilk yıllarından itibaren Devlet kurumları, kültürel etkinlikleri düzenleyici, destekleyici bir konumdadır. Dönemin etkin Millı̂ Eğitim Bakanı Hasan Ali Yücel'in öncülüğünde etkili olan politikalar hümanizm, aydınlanma, Batı düşünce formlarını doğu felsefesinde yoğurma ilkelerine dayanmaktadır. Devlet tiyatroları ve konservatuarının, köy enstitülerinin kurulması, millî kütüphane kurma çabalarının başlaması dönemin önemli kazanımları arasında sayılabilmektedir (Hızarcı, 2015, s. 16). Özellikle 1932 yılında, bugünkü adı Gazi Eğitim Fakültesi olan Gazi Terbiye Enstitüsü bünyesinde Resim-İş Eğitimi bölümünün kurulması ve yurdun dört bir yanında görev yapacak olan sanat eğitimcilerinin yetiştirilmesinin amaçlanması oldukça önemli bir gelişmedir. Bu bölümden mezun olanlar hem sanatçı hemde öğretmen vasıfları ile Anadolunun dört bir yanında hem sanatsal üretimlerini gerçekleştirmiş ve bulundıkları bölgelerde açtıkları sergilerle etkin olmuşlar hem de yetiştirdikleri öğrencilerle oldukça önemli bir görev üstlenmişlerdir.

1930-50 yılları arasında 1931 yılında Türk Tarih Kurumunun ve 1932 yılında Türk Dil Kurumunun ve yine 1932 yılında halkevlerinin açılması oldukça önemlidir. 1938- 1944 yılları arasında her yıl 10 sanatçının yurdun çeşitli illerine gönderilerek gitmiş oldukları yörelerin folklorik kültürlerini inceleyerek eserlerine yansıtmalarının amaçlandığı yurt gezileri gerçekleştirilmiş bu gezileri takip eden süreçte yurt gezileri sergileri tertiplenmiştir. Bu sayede ulusal bir plastik sanatlar dilinin gelişimi ve halkın bu kültür politasını çeşitli illerde açılan sergiler aracılığı ile izlemesi ve benimsemeleri hedeflenmiştir (Bek, 2008, s. 119).

1960 sonrası ve 1970'li yıllarda, kültür politikalarında devlet katkısı Kültür Bakanlığının kurulması ile daha da artmış ve daha planlı-programlı bir hal almıştır. Bu yıllarda çeşitli illerde devlet galerileri kurulmaya başlanmış ve düzenli sergiler organize edilmeye başlanmıştır. Düzenlenen sergilerin basılı katalogları farklı illerdeki sanatseverlerin de bu eserleri görmelerine imkân tanımaktadır. Yabancı sermaye kuruluşlarının finansörlüğünde ortaya çıkan kültür-sanat merkezleri, eğitim kurumları ve bankaların yanı sıra, özel galerilerin sayılarındaki artışla birlikte sanatçıların eserlerini sergileme olanakları çoğalmış, koleksiyonculuk bu yıllarda yaygınlaşmaya başlamış bu sayede ticari sanat piyasasının oluşması yönünde önemli adımlar atılmıştır. Yine bu yıllarda sanat yayınlarının sayısında artış söz konusudur (Bek, 2007, s. 71). Sanat ortamlarındaki bu hareketlilikte sanat eğitimi veren kurumların etkileri de ayrı değerlendirilemez lakin bu yıllarda etkili olan 
sanatçıların büyük bir bölümü sanat eğitimi kurumlarında sanatçı- sanat eğitimcisi misyonu ile hareket etmekte olan akademisyenlerdir.

Türkiye'nin kültür politikalarını Devlet Planlama Teşkilatının kurulması ve beşer yıllık kalkınma planlarını oluşturmaları sonucunda daha açık bir şekilde incelemek ve değerlendirmek mümkün olmuştur. Genellikle bu metinlerde "kültürel zenginliğimizin ve çeşitliliğimizin korunması, geliştirilmesi ve gelecek kuşaklara aktarılmasının” kültürel politikalarımızın temelini oluşturduğu görülebilir. Cumhuriyet'in ilanından günümüze değin devletin ve kurumların sanat üzerindeki destekleyici politikasının dönem dönem azalıp artmakla birlikte devam ettiği söylenebilir.

\section{Sanatta ve Sanat Eğitiminde Değişim}

Hiç kuşkusuz toplumsal değişimler paralelinde gelişen tüm değişkenlerle birlikte toplumun eğitim sisteminden beklediği değerler ve buna bağlı olarak eğitimin amaç, yöntem ve uygulamasında okul düzeyine yansıyan değişiklikler de söz konusu olmuştur (Kırışoğlu, 2005, s. 13). Bu değişimlerde toplumsal gidişat ve gereksinimler kadar ülkelerin eğitim politikaları da belirleyici rol oynamaktadır.

"Sanat eğitimi" kavramı, tüm dünyada ve özellikle ülkemizde anlamı oldukça tartışmalı bir konu olup ilk amacının "sanatın öğretilmesi mi" yoksa "insanın sanat yoluyla eğitilmesi mi" gerektiği sorunsalı hâlen varlığını sürdürmektedir (San, 2010, s. 13). Toplumsal değişimlerle birlikte yaşanan kültürel değişimlerin sonucunda sanat alanında da sanatın eğitiminde de değişikler yaşanmıştır. Read'e göre sanat, toplumsal gelişimin bir yan ürünü değildir; daha ziyade, bir toplumdan gelen özgün unsurlardan biridir (Read, 2018, s. 23). Sanat eğitimi üzerindeki anlayış ve yaklaşımlar en az iki yüzyıl boyunca sanat eğitiminin yapısının bir gereği olarak ussalık yani rasyonellik ve usdışılık yani irrasyonelik arasında gidip gelmiş ve 20. yüzyıl ortalarına dek usdışılık olarak tabir edilen sanatsallık, duygusallık ağır basmıştır. Günümüzde ise özellikle bilim ve teknolojideki büyük ilerlemelerle birlikte 1950'lerden sonra giderek belirginleşen ussal bir tutuma, aslında bir bakıma çağımızın da gereği olan bir ussallaştırmaya doğru yönelinmiştir (San, 2010, s. 13).

Sanatların insanın eğitimindeki önemi ve gerekliliği konusunda söylenmiş sözlere ve yazılı düşüncelere en başta Platon ve Aristoteles'den başlamak üzere antik devirlerden bu yana rastlanılmaktadır. Eğitim-öğretim çağındaki yetişmekte olan çocukların ve gençlerin okul içinde ve dışındaki genel eğitiminin bir parçası olarak sanatsal alanda eğitilmesinden söz edilmesinin Batıda barok dönemin bitişiyle, Endüstri çağının etkileriyle toplumsal değişimler sonucu ortaya çıkan ve güçlenip yönetim kademesinde de söz sahibi olmaya başlayan kentsoylu sınıfının kendisiyle ilgili bir takım eğitimsel tasarımlar geliştirmesi ve sanat eğitiminin bireyler üzerindeki olumlu etkilerinden yola çıkılarak uyumlu kişilikler yetiştirmek gibi düşüncelerle başladığı söylenilebilir (San, 2010, s. 55).

\section{Batı'da Sanat Eğitiminin Geçirdiği Değişimler}

Sanatın bir ders olarak eğitim kurumlarına girmesi Batı' da 19. yüzyılda başlayan Endüstri Çağı ile gerçekleşmiştir. Ticaret bilinci güçlü ve ağır basan 19. yüzyılda sanat eğitiminde estetikten çok tecimsel amaç yeğlenmiştir (Steveni'den aktaran Kırışoğlu, 2005, s. 15). Batı'da 18 ve 19. yüzyılda toplumsal yaşamı da etkileyen baş döndürücü gelişmeler sanat eğitiminin işlevinin de değişmesine neden olmuştur. İlk başlarda Batı'da Endüstri Çağı ile okullara girmeye başlayan sanat eğitimi dönemin endüstriyel üretimine fayda sağlamak üzere planlanmış, fabrikalarda basit ürün tasarımları yapabilecek nitelikte personel ihtiyacının doğması sorunsalına bir çözüm üretebilmek adına yürürlüğe konmuştur. 18 ve 19. yüzyıl başında sanat eğitimi felsefi, bilimsel, politik ve toplumsal birçok nedenden ötürü bağımsızca gelişememiştir. 19. yüzyıl bile hâlâ sanat eğitimi açısından "karanlık ortaçă̆" dır. 19. 
yüzyılın yarısından başlayarak İngiltere, Almanya gibi ülkelerde sanat eğitimi hareketleri ve uluslararası kongrelerle sanat eğitiminin mevcut konumu, amacı ve geleceği tartışılmaya başlanılmıştır (San, 2010, s. 57).

19. yüzyılın son çeyreğinde yaşanan küresel buhranların da etkisiyle yaşanan kültürel çöküşün ve insanın kendine yabancılaşmasına karşı koymak için eğitimde güzel sanatlar yoluyla genel bir reform yapmak yönünde bazı çabalara girişilmiştir. "Sanat eğitimi akımı" adı verilen bu girişimler özetle güzel sanatlar alanlarındaki disiplinlerin yaratıcı faaliyetlerini ve bu faaliyetlerin doğurduğu estetik haz ediniminin bireyin üzerinde yaratacağı olumlu etkiler göz önünde bulundurularak eğitim ve öğretimin esas alanı hâline getirmektir. Bu akım aynı zamanda tüm çağdaş eğitim reformlarını da etkilemiştir (Aytaç, 2019, s. 19).

Sanat eğitimini doğrudan ya da dolaylı etkileyen psikoloji, felsefe, estetik, sosyoloji, antropoloji gibi bilim alanlarındaki gelişmeler de aynı şekilde sanat eğitiminde köklü değişikliklerin yaşanmasına neden olmuştur (Kırışoğlu, 2005, s. 13). Bu gelişmeler ışığında filizlenen düşünce biçimleri sonucunda 19. yüzyıl sonlarına doğru sanat eğitiminde amaç, endüstrinin hizmetinden kişinin estetik yargı ve becerisinin geliştirilmesine kaymıştır. Yine aynı yıllarda İsviçreli pedagog Pestalozzi (1746-1827) sanat eğitimi derslerinin diğer eğitim dersleri ile ilişkisini kurarak çocuğun uşsal gelişimini güçlendirmeyi amaçlamıştır. Batı'da İngiliz W. Smith, J. Ruskin gibi sanat eğitimcilerinin öğretileri ilk başlarda etkili olmuş ve sanatın yetenek işi değil basitten karmaşığa doğru giden bir öğrenme işi olduğu fikri benimsenmiştir (Kırışoğlu, 2005, s. 17). Özetlenecek olursa Batı'da sanat eğitimi veren yüksek eğitim kurumları yapısal ve ilkesel olarak ilk olarak sanat eğitiminin bireyin öz gelişiminin bir gerekliliği olduğu ilkesinin benimsenmesi sonucunda sanatçı yetiştirmeyi hedefleyen ve sanat eğitimcisi yetiştirmeyi hedefleyen kurumlar olarak birbirinden ayrılarak bir dönüşüm yaşamıştır.

\section{Türkiye'de Sanat Eğitiminin Geçirdiği Değişimler}

Türkiye'de Batılı anlamda ilk sanat eğitimi hareketleri, 1908 tarihli II. Meşrutiyetin ilanı ile başlamış olsa da sanat eğitimi gerçek anlamda Cumhuriyet'in ilanından sonra büyük aşama kaydetmiş̧ir (Berk, 1973, s. 107). Cumhuriyet'in ilanından önce Osmanlı Devletinde Mühendishane-i Berri Humayun'da (Kara Harp Okulu) teknik anlamda verilmeye başlanan dersler Osmanlı Devleti'nin Batılılaşma hareketlerinin bir yansımasıdır. Politik amaçları olan Batılılaşma hareketleri ülkenin çeşitli kurumlarında alelacele ve temellendirilmeden uygulamaya konulan Batı hayranlığının ve Batı dünyasından geri kalmışlığın yarattığı psikolojinin bir sonucudur. Meşrutiyet'in ilanı toplumsal ve kültürel alanda birçok yenilik ve değişimi de beraberinde getirmiş, Cumhuriyet'in ilanı Türkiye'de sanat eğitiminin gelişimi açısından son derece önemli bir ivme kazandırmıştır. Genç Cumhuriyet'in toplumsal amaçlarından birisi de ulusal kimliği olan bir sanat dili oluşturabilmektir. Cumhuriyet'in ilanının getirmiş olduğu yeniliklere açık politik koşullar sanat eğitiminde hızlı ilerlemelere ortam hazırlamıştır. O yıllarda bizzat Atatürk'ün direktifleri ile yurda davet edilen ünlü eğitimciler hazırladıkları raporlarla sanat eğitiminin gelişiminin önemli adımlarını atmışlardır (Yaman, 1994, s. 156).

Ülkemizde Cumhuriyet'in ilanı toplumsal ve kültürel alanda büyük etkileri ve getirileri olan çok önemli ve hayati bir değişimdir. Cumhuriyet'in ilanından önce Osmanlı Devleti'nde başlayan "Batılılaşma" hareketi Cumhuriyet Türkiye'sinde Batılaşma hareketlerinden farklı dinamikleri olan "çağdaşlaşma" harekeleri şeklinde sürmüştür (Berkes, 2016, s. 486). Resim dersleri Batıda endüstrileşmenin bir gereği ve ihtiyacı olarak okul programlarında yer almışken ülkemizdeki gerekçesi çağdaşlaşma hareketlerine büyük katkısı olacağı inancıdır. Cumhuriyet öncesinde çağdaşlaşma 
Batılılaşma ile eş anlamlı tutulmuştur. Cumhuriyet döneminde ise çağdaşlaşma, Batılılaşmadan çok evrensel değerlere ulaşma amacı taşımaktadır (Kırışoğlu, 2009, s. 18). Türkiye'de sanat eğitiminin tarihi Batılı ülkelerle benzer bir çizgiyi izlemiştir. Hatta sanat eğitimi ile ilgili benzer söylemler öteki ülkelerle eş zamanlılık bile göstermiştir fakat ülkemizin toplumsal, kültürel, politik ve tarihsel yapısı ve dönemin koşulları bu benzerliğin zaman zaman dışında bir görünüm vermesine neden olmuştur (Kırışoğlu, 2009, s. 17). Cumhuriyet Döneminin sanat eğitimi açısından en büyük kazanımlarından birisi de Türkiye'de sanat eğitimi kurumlarının nitelik ve nicelik olarak iyileştirilmesidir. Osmanlı Devleti döneminde kurulmuş olan ilk güzel sanatlar eğitimi kurumu olan Sanayii-Nefise Mektebi, Cumhuriyet döneminde “Devlet Güzel Sanatlar Akademisi” adını almış ve 1926'da Namık İsmail bu kurumun müdürlügüne atanmıştır (Turani, 1977, s. 11). Bu değişim sadece bir tabela değişikliği olarak kalmamış, ulusal bir sanat yaratma çabaları bu dönemde olumlu bir ivme kazanmışıı. Cumhuriyet'in ilk yıllarından itibaren Türkiye'de sanatsal hareketler Güzel Sanatlar Akademisinin etrafında ve öncülüğünde şekillenmiştir. $\mathrm{Bu}$ yıllarda düzenli sergi ve etkinliklerin ağırlıkta olarak akademi hocaları ve öğrencileri tarafından gerçekleştirildikleri görülmektedir (Sönmez, 2019, s. 18). Erken dönem Cumhuriyet Türkiye'sinde sanat alanında yaşanan önemli gelişmelerden biri de bir eğitim ve kültür politikası neticesinde devlet bursu ya da özel imkânlarıyla yurt dışında sanat eğitimi alıp yurda dönen sanatçıların o yıllarda Avrupa sanatında etkileri sürmekte olan kübizm akımından etkilenmeleri ve ülkeye getirmeleri olmuştur. $\mathrm{O}$ yıllarda kübizm adeta modern sanat ile özdeşleşmiş hâldedir. Yurt dışında sanat eğitimi alan sanatçıların kurmuş olduğu "d grubu" Türkiye de kübizm akımının temsilcileri ve savunucuları konumundadır ve gerek açtıkları sergiler gerekse basın yoluyla modernizmin resim sanatındaki karşılığının kübizm olduğu halka benimsetilmeye çalışılmıştır. Türkiye' de o yıllarda sanat alanında bir diğer önemli yönelim ve değişim ise Akademi mezunu bir grup genç sanatçının D grubunun sanat anlayışına tepkisel bir yönü de bulunan, sanatsal çıkış noktası "gerçekçilik" olan yeniler grubunun kurulması ve 10 Mayıs 1941 yılında ilk sergilerini açmaları sayılabilir. Bu olay sanat alanında çokseslilik anlamında önemli görülmektedir (Sönmez, 2019, s. 14).

“Genç Cumhuriyet Türkiye' sinde 1923-1950 yılları arasında devletin kültür-sanat politikasında, üç ana fikrin ortaya çıktı̆̆ı görülmektedir. Bunlar; ulusal bir sanat dili yaratma, ulusal olan sanatın modern ve çağdaş olmasını sağlama, ulusal, çağdaş sanatının oluşmasında güzel sanatlar eğitimine ağırlık vermektir." (Yaman, 1994, s. 156). Sanat bu yıllarda aynı zamanda bir propaganda aracı olmuş ve Cumhuriyet'in getirdiği yenilikler toplumcu-gerçekçi bir bakış açısıyla sanatçıların eserleri aracılığı ile yansıtılmıştır. Yurt gezileri, devlet resim-heykel yarışmaları, yurdun çeşitli meydanlarına yapılan anıt ve heykeller, yurt dişına sanat eğitimi almak üzere gönderilen sanatçılar Cumhuriyet'in kazanımlarının sanat alanındaki yansımalarından sadece bir kaçıdır. Sanat eğitimi bu yıllarda reformist bir yapıdadır ve önemli atılımlar sağlamış ve günümüze kadar gelen süreçte bazı değişimlerle bugünkü yapısal halini almıştır. Türkiye' de 1955 de Devlet Tatbiki Güzel Sanatlar Yüksekokulu olarak açılan ve bugünkü adı Marmara Üniversitesi Güzel Sanatlar Fakültesi olan sanat eğitimi kurumu Bauhaus ekolünde eğitim vermesi de oldukça önemlidir. Bu okulda güncel sanat uygulamaları, deneysel atölye çalışmaları ve kavramsal sanat pratiklerinin uygulanması bu okuldan mezun olan sanatçıların Türkiye'de çağdaş sanat hareketleri içerisinde önemli katkılar yaptıkları gözlemlenmektedir

20. yy sanatsal içerik açısından çok büyük devrimlerin yaşandığı bir yüzyıldır. 20. yy'ın başlarında eğitim hareketi "tasarım elamanlarına dayalı" , 20. yy'ın başından ortalarına kadar eğitim hareketi “yaratıcı kişisel ifadeye" 1930'lardan 60'lara kadarki eğitim hareketi "güncel yaşamda sanat 
anlayışına", 1960-1990 arası eğitim hareketi de "sanatı bir disiplin olarak" kabul eder (Aksoy'dan aktaran Pasin, 2004, s. 193).

Günümüz bilgi toplumlarında sanat eğitiminin "görsel kültür eğitimi" ve "medya okuryazarlığı" ile yapısal bir bütünleşme içerisine girmesi beklenilmektedir. Görsel kültür eğitimi; sanatın bağlamsal olarak düşünülmesi, kültürelliğin daha fazla dâhil edilmesi ve sosyalliğe yaptığ1 vurguyla gündeme gelerek sanat eğitimine farklı bir bakış açısı getirmiştir." (Finkelstein, 2007'den aktaran Sengir, 2015, s. 251). Medyayı ve medya okuryazarlığı süreçlerini sanat eğitimsel süreçlerle eşleşik tutmamıza olanak sağlayan temel etken, özellikle kültürün giderek medyalaşmasıdır denilebilir (Eker ve Aslan, 2010, s. 257).

Medya okuryazarlığının sanat eğitimine uyarlanması ve adaptasyonu, medyanın iletilerinin çözümlenmesinde ve anlaşılabilir kılınmasında belli bağlamları zorunlu olarak ele almaktadır. Medya ile kültür arasındaki etkileşimden doğan görsel kültür, çağımızın temel nitelemelerinden biri olarak da kullanılmaktadır. Günümüzde bir çeşit görsel kültür çağının içinde olduğumuz da ifade edilebilir. Medya endüstrisinin üretimlerinin çoğu, görsellik içeren ürünlerdir. Görsel kültür çağı, medya eğitiminin ve dolayısıyla medya okuryazarlığının yeniden tanımlanması gereğini de ortaya koymuştur (Eker ve Aslan, 2010, s. 259).

Türkiye' de toplumsal ve kültürel alanda yaşanan değişimleri gözlemleyebilmenin bir yolu da toplumsal ve kültürel alışkanlıkların değişimlerini gözlemleyebilmektir. Bu değişimler ağırlıklı olarak teknolojik gelişmelerin yansıması olarak ortaya çıkmıştır.

Günümüz bilgi toplumu büyük bir dönüşüm yaşamaktadır. Teknolojik gelişmelerin ve uluslararası telekomünasyon ağının, küreselleşmenin, popüler kültürün etkisindeki toplumun kültürel yapısındaki bu hızlı ve karşı konulamaz değişim teknolojinin getirdiği yeniliklerle birleşince sanat eğitiminde değişim de zorunlu olarak ortaya çıkmaktadır. Fotoğraf makinesinin icadıyla daha önemli bir hal alan teknoloji ile sanatın ilişkisi günümüzde yeni teknolojik olanakların artmasıyla çeşitlenmiş ve "dijital sanat" kavramını doğurmuştur. Günümüzde dünyanın çeşitli yerlerinde dijital sanat müzeleri açılmakta ve yoğun ilgiyle karşılaşmaktadır. Bu gelişmeye koşut olarak da sanat eğitimi kurumlarında dijital sanat kavramı ve eğitimi gündeme gelmiştir.

Günümüz insanı, değişen gündelik yaşam biçimi ve alışkanlıklarıyla her anlamda daha dar bir yaşam alanında ve topluma daha az entegre olarak yaşamayı tercih etmektedir. Basılmış gazete, dergi ve kitaplar yerlerini elektronik ve sesli gazete, dergi ve kitaplara bırakırken interaktif sanal sergi ve müze turları, çevrimiçi konser ve eğitimler insanın neredeyse odasından çıkmadan birçok etkileşimli kültürel etkinliğe erişimine olanak vermektedir. Tüm bu gelişmeler ve yenilikler bilişim sektörlerinde rekabetçi ve yenilikçi tasarım ihtiyaçlarını beraberinde getirmiş ve yükseköğretim kademesinde sanat eğitimi kurumları bu gereksinime cevap verebilecek şekilde eğitim-öğretim müfredatlarını ve hatta isimlerini değiştirmiştir. Bu bağlamda birçok güzel sanatlar fakültesi adını "Sanat ve Tasarım Fakültesi”, "Güzel Sanatlar ve Tasarım Fakültesi” "Güzel Sanatlar, Tasarım ve Mimarlık Fakültesi “ olarak değiştirdikleri gözlemlenmiştir. Bu değişimler sadece isim ve tabela değişikliği olarak kalmamış ilgili kurumlar eğitim programlarını da bu yönde revize etmişlerdir.

\section{Görsel Kültür ve Medya Okur-Yazarlığının Sanat Eğitimine Yansımaları}

Görsel Kültür, hakkında net ve kesin tanımlamalar olmasa da hatta yükselen yeni bir disiplin mi yoksa interdisipliner bir geçiş alanı mı olduğu sorunsallarıyla birlikte hâlen tartışılıyor olsa da 1970'li yıllardan itibaren modernleşme hareketlerinin etkisiyle ortaya çıkan sonra giderek gelişen bir çalışma 
alanı olarak görsel olguya, görsel olaya, imgelere, görsel pratiklere, görme, bakış, gösteri, temsil, izleyicilik, röntgencilik, gözetim ve dijitalleşen imge gibi konulara yönelen, bu konulardaki çoklu incelemelerin gerçekleştirildiği bir alan olarak dikkat çekmektedir (Çakır, 2014, s. 9). Görsel Kültür, kaynağını medyanın ürettiği ve ilettiği görsellikten alır ve çağımızda sözsel-işitsel kültür ürünlerinin yerini artık görsel kültür ürünleri almaktadır. Üretilen görüntü, insan eliyle ortaya konan, sanal bir dünyanın yansıması, bir çeşit simülasyonudur. Bu simülasyonun bir parçası olan simge, gerçeğin görsel bir temsili, felsefi içerikler de barındıran bir yansımasıdır. Bu simülasyon ticari bir amaç güden tüketim toplumunun doğrudan önemli bir dinamiğini oluş̧turur.

Son ylllarda kültür içindeki imgelerin, görüntülerin, görselliğin ve gösterisel olanın yaygınlaşması, kültürel ürünlerin içinde daha fazla yer bulması söz konusu olmuştur. Bu durum medya, kültür ve sanat alanları ile multidisipliner bir nitelik kazanmıştır. Özellikle iletişim araçlarının, fotoğrafın, sinema filmlerinin, televizyonun, sanat alanının ve internetin görsel olan her şeyi çok fazla kullanması, görselliği kullanarak varlıklarını sürdürmeleri bu konuların çok alanlı perspektiflerle incelenmelerini gerekli kılmıştır. Bu incelemelerin bir arada değerlendirildiği alanın adı Görsel Kültür'dür (Çakır, 2014, s. 158).

Görsel Kültür kavramını açıklarken "görsel" kelimesinin karşılığını da ortaya koymak gerekir. Görsel kültür kavramının içinde geçen görsel kelimesi tüm görülebilenlerin bir karşıllğ̆ olan "görüntü" kavramıyla karıştırılmamalıdır. Görsel kelimesi bu tanımda "insanlar tarafından üretilmiş, yorumlanmış veya meydana getirilmiş, işlevsel, iletişimsel ve estetik amacı olan her şey" olarak ifade edilmektedir (Barnard'dan aktaran Eker ve Aslan, 2010, s. 187). “Günümüz sanatı nasıl salt renklerin, biçimlerin, seslerin, hareketlerin uyumlu birlikteliğinden doğan güzellikler yaratmakla yetinmeyip tarihsel, kültürel, toplumsal ve politik olay ve olguları eleştirel bir yaklaşımla irdelemeye yöneliyorsa sanat ve kültür eğitimi de bu dinamikleri dikkate almak zorundadır." (Kırışoğlu, 2014, s. 9).

Günümüzde sanatı ve dolayısıyla sanat eğitimini kültürel bileşenlerle birlikte düşünmemize katkı sağlayan sosyal, iletişimsel ve teknolojik gelişmeler söz konusudur. Enformatik iletişimin baş döndürücü bir hızda gerçekleştiği günümüzde küreselleşme, etki alanındaki küresel kitle kültürü, popüler kültür ve görsel kültür dinamiklerini de etkileyen, yönlendiren en önemli unsurların başında gelmektedir. Görsel kültürü büyük ölçüde medya üretimlerinin oluşturması, günümüzde sanat eğitimi ile medya üretimlerini birlikte düşünme gerekliliğini ortaya koymaktadır. Görsel kültürü büyük oranda şekillendiren medya üretimleri çağdaş sanat eğitiminin bu söz konusu çoklu okuryazarlıklardan faydalanmasını, sanat eğitiminin bu multidisipliner yapıyı çözümlenmesindeki katkısını zorunlu kılmaktadır. Medya organlarının üretimleri olan görsel kurgular, görsel metinler veya görsel mesajlar medya okuryazarlığının önemli bir alanını teşkil ettiği için çağımızın bir gereği olarak sanat ve onun eğitimiyle de ilişkilendirilmek durumundadır. Bu nedenlerden dolayı medya okuryazarlığının sanat eğitimi metodojileri ile genişletilmesi gereği önemli görülmelidir (Eker ve Aslan, 2010, s. 187).

Görsel kültür eğitimi; günümüzde kültürelliğin sanata daha fazla dâhil edilmesi ve sosyalliğe yaptığ1 vurguyla gündeme gelerek sanatın bağlamsal olarak düşünülmesini savunmuş ve sanat eğitimine farklı bir bakış açısı getirmiştir. Sanat eğitiminin kazanımları da bu perspektiften değişimler yaşamakta, öğrenci okulda öğrendiği bilgileri gündelik hayatına uyarlayabilmeli ve diş dünyayı anlamlandırabilmelidir. Bu stratejik sanat eğitimi kurgusu görsel kültür eğitiminin önemli bir yanıdır."Görsellikteki kültürel vurgu, gördüğümüz şeyin, dişarıdaki gerçekliğin aynadaki yansımasıdır; yüzeydeki görüntü güvenilir bir kayıttır ve aslında görünüş gerçektir." (Finkelstein'den aktaran Sengir, 2015, s. 271). 1970'li yıllar itibarıyla kültür ve medya çalışmaları "Görsel Kültür" konusundadır. Günümüz sanat anlayışının kültürel dinamiklerinin daha fazla olması, medyanın 
görselliği daha kültürel bileşenlerle ve alıntılarla sunması, iletilen her görselliğin görüntüsünün bize sunduğu anlam dışında metaforik alt anlamlarının da bulunması ve güncel sanat pratiklerinin sanat eğitimi perspektifinden okunmasının bu minvalde daha da güçleşmesi görsel kültür çalışmalarının pedagojik bir yapılandırılması ihtiyacını söz konusu hâle getirmiştir. Birçok ülkede görsel kültür çalışmaları hızlanmış ve ilk olarak 1991'de İngiltere'de Derby Üniversitesinde bir lisans dalı olarak açılmıştır (Çakır, 2014, s. 161).

Son yıllarda Görsel Kültür'ün üretim ve iletim aracı olarak medyayı kullanması ve medyanın sunduğu görsel medya iletilerin çözümlenmesinde belli bağlamları zorunlu olarak ele almak gerekmektedir. Kültür, tarih, sanat, ekonomi, toplumsallık gibi konular, medya metinlerinin ilişkili olduğu temel alanlardır. Bu alanlarının dışında, medya metinlerinin dilleri, türleri, karakteristikleri bunlara ait sistemleri, bahsettiğimiz alanlarıyla ilişkisinde daha da önemli görülmektedir. Medya ile kültür arasındaki etkileşimden doğan görsel kültür, çağımızın temel nitelemelerinden biri olarak da kullanılmaktadır. Günümüzde medya sektörünün üretimlerinin büyük bir bölümü görsellik içeren ürünlerdir. Artık izleyici adeta görsel bir bombardımana maruz bırakılmaktadır. Bu bağlamda görsel kültür çağı, medya eğitiminin ve dolayısıyla medya okuryazarlığının anlaşılabilmesi, yeniden tanımlanması gereğini de ortaya koymuştur (Eker ve Aslan, 2010, s. 187).

\section{Bulgular}

-Cumhuriyetin ilk yıllarından itibaren yurdun dört bir yanına ulaştııılmaya çalışılan çağdaşlaşma hareketleri görülmektedir. Bu yıllarda geleneksel olanın modern olanla değişimi söz konusudur (Sunar, 2019, s. 23).

- Dünyada ve ülkemizde sanat eğitimindeki değişimlerin iki ana etken neticesinde değişimler yaşadığı görülmüştür. Birinci etken çağın getirdiği değişimlerin paralelinde güncel sanat alanlarındaki değişime bağlı olarak sanat eğitiminde yaşanan değişimlerdir. İkinci etken ülkelerin eğitim ve kültür politikalarındaki değişimlere bağlı olarak sanat eğitimi alanında yaşanan değişimlerdir (Kırışoğlu, 2005, s.13).

-Ülkemizde sanat eğitiminin geçirdiği önemli değişimlerin başında özellikle erken dönem Cumhuriyet Türkiye'sinde sanat eğitiminin çağdaşlaşma hareketlerinin bir gereği olarak görülmesi ve bu minvalde tüm devlet kurumlarının ortak bir ülkü doğrultusunda iyileştirme çabalarına girişmeleridir.

-Cumhuriyetin ilk yıllarından itibaren sanatta ervrensellik, ulusallık tartışmaları süregelmiştir. Bu tartışmalar gölgesinde belli dönemlerde sanatta bir ulusallık arayışı söz konusu olmuş ve devlet politası gereği ulusal bir sanat kimliği oluşturma çabaları görülmüştür. Bu çabaların günümüzde eskisi kadar gündemde olmadığı da bir gerçektir.

-Sanattaki ulusal kimlik arayışları sanat eğitiminde de karşılık bulmuş ve geleneksel sanatlar, folklorik kültürel öğeler sanat eğitiminde bir kazanım olarak programlarda daha fazla yer bulmaya başlamıştır.

-“Postmodern sanatın toplumsal konulara, tarihe, kültüre, politikaya gönderme yapan söylemleri ve eylemleri sanatta biçimci estetiğin önüne geçmiştir. Bu anlamda kültürel çözümlemer, düşünceler ve anlamlar biçim kaygılarından ve ustalıktan daha önemli görülmeye başlanmıştır." (Bamford'dan aktaran Kırışoğlu, 2009, s.35). 
- Türkiye'de 70'lerin sonlarından itibaren, özellikle 80'lerde fikir ve kavramın plastik yapıtın önüne geçtiği Kavramsal sanat denemeleri görmeye başlanmaktadır. Bu yıllarda sanatçıların resim ve heykelin ötesinde deneysel çalışmalar yaptıkları ve gerek üretim teknikleri ve gerekse sunuş yöntemleri açısından daha özgür bir ortam yarattıkları görülmektedir.

-Ülkemizde sanat eğitiminin başlangıcıdan günümüze değin birçok değişim yaşanmıştır. Bu değişimler yapısal ve ilkesel olarak farklılaşabilmektedir. Sanat eğitimi veren yükseköğretim kurumlarındaki yapısal değişimler dönemler hâlinde çağın gereksinimlerine ayak uydurmak için zorunlu hâle gelmiştir. İlkesel değişimlerin ise daha az sayıda gerçekleştiği görülmektedir.

- Günümüz bilgi çağında teknolojik gelişmelerin de etkisiyle sanat ve teknoloji etkileşimi her geçen yıl daha da artmaktadır. Bu etkileşim sanat eğitiminde de karşılığını bularak sanat eğitiminde teknolojik araç- gereç ve yöntemlerinin eğitimi ihtiyacı daha yoğun bir şekilde hissedilmektedir.

-Türkiye'de sanat eğitimi veren yükseköğretim kurumlarında teknolojik altyapı ve dönüşüm yeterli değildir ve hızla tamamlanmalıdır.

-Çokkültürlülüğün günümüz sanat eğitimine adaptasyonu sağlanmalı ve postmodern sanatsal ifadeler bu bakış açısı altında anlamlandırılmalıdır.

-Görsel kültür ve Medya okur-yazarlığı gibi yeni filizlenen disiplinlerin sanat eğitimine entagrasyonu çağın bir gerekliliği hâline gelmiştir.

-“Kültür ve eğitim politikaları yerel, evrensel, geleneksel ve yeni teknolojileri kapsayacak şekilde yapılandırılmalıdır."(Kırışoğlu, 2009, s. 41).

\section{Sonuç}

Dönüşme, değişme, başkalaşma gibi kavramlar yaşamın kaçınılmaz gerçeklerinden bazılarıdır. Toplumlar ve kültürler yaşayan bir organizmaya benzetilecek olursa yaşayan her canlı gibi bir değişime mecburdur. İnsanoğlu yaşamakta olduğu çevreyi kendi yaşam koşullarına uyumlu hâle getirmek üzere değiştirmiştir. Tüm bu değişim olgusu toplumların en canlı bileşenlerinden kültürel yapıyı daha hızlı bir şekilde etkiler. Kültürler etkileşir, dönüşür ve değiş̧irler. Sanat, kültürün önemli bir yapı taşı olarak çağın sosyal, siyasal, politik yapısından etkilenir.

Postmodernizmin etkisiyle değişen kültürel yapılar ve buna bağlı olarak yine kültürel yapıların çeşitli nedenlerce dönüşüme uğramasının sonucu olarak güncel eğitim programlarında bu farklılaşmaların da analiz edildiği, çağın gereksinimlerine cevap verebilecek bir içerik belirlenmesi gereği doğmuştur. Böylelikle sanat eğitiminin geleneksel sistematik ve disiplin temelli ders programlarının daha stratejik, sosyal, kültürel, politik, ekonomik ve teknolojik bir içerik doğrultusunda değişimlere uğraması söz konusu olacaktır. Sözü edilen bu değişimin sanat eğitimindeki yansıması, görsel kültür eğitimine tekabül ederek sanat eğitiminin artık görsel kültürel bir yapıya dönüştürülmesi gerekliliği ortaya konmaktadır. Çünkü görsellik artık bizi tamamen kuşatmakta ve doğru yorumlanabilmesi, içerdiği alt metinlerin doğru okunabilmesi için eğitiminin de onu çözmeye yönelmesi çağın bir gerekliliği ve önemli görülmektedir (Sengir, 2015, s. 75).

Seçkin sanat ile popüler kültür arasındaki sınırların ortadan kalkması, sanatın kültür bağlamı içinde yeniden tanımlanması, modernist estetiğin yerini, estetik ölçütlerini popülizm ve eklektizm üzerine üzerine kuran post-modern sanat anlayışının (Şaylan'dan aktaran Kırışoğlu, 2009, s. 37) alması ve giderek her türlü görsel iletinin, görsel simgenin kültür kimliğimizi oluşturacak şekilde bizi 
etkilemesi, görsel kültür eğitiminin sanat eğitimi kapsamı içinde yer almasını zorunlu kılan nedenler arasında sayılabilir (Kırışoğlu, 2009, s. 37).

Değişen ve değişmekte olan dünyada yaşanan tüm değişimler, sanat eğitimini bu değişimlere koşut değişimlere uyum sağlamaya zorlamıştır. Çokkültürlülük de gerçekleşmesi beklenen değişimlerden birisidir. Çok kültürlülük birden çok kültürün kendi kimliğini yok saymadan diğer kültürlerle yaşaması ve yaşatılması anlamına gelmektedir. Çokkültürlülüğün programlara yansıyan biçiminde sanat eğitimi kültürlerin durağan değil değişken olduğunu öğretmesi bakımından ve küreselleşen dünyada güncel sanatın bu çok kültürlülük penceresinden okunmasını sağlması bakımından önemli görülmektedir (Kırışoğlu, 2009, s. 39).

Birbirleriyle etkileşimi hem fiziksel hem de içeriksel olarak zorunlu gören "görsel kültür" ve "medya üretimleri", çağın doğurduğu ihtiyaçların da göz önünde bulundurulmasıyla ön plana çıkmaktadır. Bu bakımdan, çağdaş sanat eğitiminin çoklu okuryazarlıklardan faydalanması kaçınılmaz görünmektedir. "Görsel Okuryazarlık" ve "Medya Okuryazarlığı" sanat eğitiminin gelecekçi yapılanmasında oldukça önemli görülmektedir. Sanat eğitiminde okuryazarlıklar konusu, sanat eğitiminin formel kurgusunun dışında özellikle medya sistemleri ile tüm halkı içine almaktadır. Görsel Kültür, daha kollektif bir yapılanmaya sahiptir. Bu bakımdan sanat eğitiminin kamusal açılımı üzerinde de ayrıca durmak gerekmektedir. Medya üretimlerinin yoğun olarak sergilediği görsel kurgular, metinler veya mesajlar medya okuryazarlığının önemli bir bölümünü oluşturduğu için sanat ve onun eğitimiyle mutlak olarak ilişkilendirilmek durumundadır. Bu gerekçe ve vesileyle medya okuryazarlığının sanat eğitimsel metotlar ve yaklaşımlar ile genişletilmesi gereği önemli görülmelidir (Eker ve Aslan, 2010, s.251).

\section{Kaynaklar}

Akın, M. H. ve Buçukçu, Ö. (2019). Türkiye'de siyasal süreçlerin toplumsal değişime etkileri. L. Sunar (Ed.), Türkiye'de toplumsal yapı ve değişim içinde (s. 93-136). Ankara: Nobel.

Aytaç, K. (2019). Çă̆daş eğitim akımları. Ankara: Doğu-Batı.

Bayar, F. (2008). Küreselleşme kavramı ve küreselleşme sürecinde Türkiye. Uluslararası Ekonomik Sorunlar Dergisi, 32, 25-34. www.mfa.gov.tr/data/Kutuphane/yayinlar/EkonomikSorunlar Dergisi /sayi32/firatbayar.pdf sayfasından erişilmiştir.

Bayhan, V. (2011). Tüketim toplumunda bireyin ontolojik mottosu: Tüketiyorum öyleyse varım. İstanbul
Üniversitesi
Sosyoloji
Konferanslarn
Dergisi,
(43),

(221-248).

https://dergipark.org.tr/tr/download/article-file/101276 sayfasından erişilmiştir.

Bek, G. (2007). 1970-1980 yılları arasinda Türkiye'de kültürel ve sanatsal ortam. Doktora Tezi. Hacettepe Üniversitesi Sosyal Bilimler Enstitüsü, Ankara.

Bek, G. (2008). Çağdaş Türk sanatında "ulusallık/evrensellik" sorunsalı ve bazı temel yaklaşımlar. Süleyman Demirel Üniversitesi Fen-Edebiyat Fakültesi Sosyal Bilimler Dergisi, (17), 117-130. https://dergipark.org.tr/en/pub/sufesosbil/issue/11421/136444 sayfasından erişilmiştir.

Belting, H. (2020). Sanat tarihinin sonu, modernizmden sonra sanat tarihi. İstanbul: İletişim.

Berk, N. (1973). 50. yılda resim sanatımız ve gelişimleri. İstanbul: Kültür ve Sanat.

Berkes, N. (2016). Türkiye'de çağdaşlaşma. İstanbul: Yapı Kredi. 
Birleşmiş Milletler İnsan Hakları Komisyonu (1949). İnsan hakları evrensel beyannamesi. https://www.ihd.org.tr/insan-haklari-evrensel-beyannames/ sayfasından erişilmiştir.

Brettell, C. B. ve Hollifield J. F. (2000). Migration theory: Talking across disciplines. New York, London: Routledge.

Çağan, K. (2006). Sanat sosyolojisinin imkânına ve inşasına dair. Bilgi Sosyal Bilimler Dergisi, (2), 11-31. https://dergipark.org.tr/en/pub/bilgisosyal/issue/29118/311506 sayfasından erişilmiştir.

Çakır, M. (2014). Görsel kültür ve küresel kitle kültürü. Ankara: Ütopya.

Çeçen, A. (1996). Kültür ve politika. Gündogan.

Eker, M. ve Aslan, H. (2010). Görsel kültür ve medya okuryazarlığı: Sanat eğitiminin kamusal açılımı. Milli Eğitim Dergisi, 40(187), 251-268. https://dergipark.org.tr/en/pub/milliegitim/issue /36197/407044. sayfasından erişilmiştir.

Ergun, D. (1984). Sosyoloji el kitabı. İstanbul: Gerçek.

Fink, A. (2009). Conducting research literature reviews: From the Internet to paper. CA: Sage.

Güvenç, B. (2013). İnsan ve kültür. İstanbul: Boyut.

Güvenç, B. (2016). Sosyal ve kültürel değişme. Ankara: Efil.

Kaya, Y. (2019). Türkiye ekonomisinin dönüşümleri 1şığında tabakalaşma. L. Sunar (Ed.), Türkiye'de toplumsal yapı ve değişim içinde (s. 71-92). Ankara: Nobel.

Kırışoğlu, O. T. (2005). Sanatta eğitim, görmek, öğrenmek, yaratmak. Ankara: Pegem.

Kırışoğlu, O. T. (2009). Sanat kültür yaratıcllık görsel sanatlar ve kültür eğitimi-öğretimi. Ankara: Pegem.

Kırışoğlu, O. T. (2014). Sanat bir serüven: Bilgi, düşünme, düşlem, tasarım, uygulama, yapıt. Ankara: Pegem.

Kocacık, F. (2003). Bilgi toplumu ve Türkiye. CÜ Sosyal Bilimler Dergisi, 27(1), 1-10. https://www.academia.edu/22123253/B\%C4\%B0LG\%C4\%B0_TOPLUMU_VE_T\%C3\%9CRK\% C4\%BOYE_Faruk_Kocac\%C4\%B1k sayfasından erişilmiştir.

Kongar, E. (2001). Küresel terör ve Türkiye. İstanbul: Remzi.

Meder, M. (2001). Bilgi toplumu ve toplumsal değişim. Pamukkale Üniversitesi Eğitim Fakültesi Dergisi, 9(9), 72-81. https://dergipark.org.tr/tr/pub/pauefd/issue/11134/133165 sayfasından erişilmiştir.

Oğuz, E. (2015). Günümüz sanatından güncel kesitler: Küreselleşmenin Sanata etkileri, postsanat, ilişkisel sanat ve temellük sanatı hakkında. Sanat ve Tasarm Dergisi, 5(2), 72-87. https://doi.org/10.20488/austd.36081

Oskay, Ü. (1971). Toplumsal gelişmede radyo ve televizyon. Ankara: Ankara Üniversitesi Siyasal Bilgiler Fakültesi.

Ozankaya, Ö. (1984). Temel toplumbilim terimleri sözlüğ̈̈. Ankara: Savaş.

Özlem, D. (2000). Kültür bilimleri ve kültür felsefesi. İstanbul: İnkîlap.

Özsoy, A. (2011). Televizyon ve izleyici. Ankara: Ütopya.

Pasin, G. (2004, Nisan). Kültürel süreçler ve sanat eğitimi. 2. Sanat Eğitimi Sempozyumu'nda sunulmuş bildiri, Gazi Üniversitesi, Ankara. 
Read, H. (2018). Sanat ve toplum. İstanbul: Hayalperest.

San, İ. (2010). Sanat eğitimi kuramları. Ankara: Ütopya.

Sengir, S. (2015). Kültürel değişkenler örüntüsünde sanat eğitiminin görsel kültür eğitimine dönüşüm gerekçeleri. Elektronik Sosyal Bilimler Dergisi, 14(54). https://doi.org/10.17755/esosder.52171

Sönmez, N. (2019). Paris tecrübleri, Ecole de Paris-Çağdaş Türk Sanatı: 1945-1965. İstanbul: Yapı Kredi.

Strasser, H. ve Randall, S. C. (1981). An introduction to theories of social change. UK: Routledge \& Kegan Paul.

Sunar, L. (2018). Değişim sosyolojisi, kavramlar, kuramlar ve yaklaşımlar. Ankara: Nobel.

Sunar, L. (Ed.). (2019). Türkiye'de toplumsal değişim. Ankara: Nobel.

Tan, M. (1981). Toplumbilimine giriş: Temel kavramlar. Ankara: Ankara Üniversitesi Eğitim Fakültesi.

Tezcan, M. (1998). Toplumsal değişme ve eğitim. Ankara: Ankara Üniversitesi Eğitim Bilimleri Fakültesi.

Turani, A. (1977). Batı anlayışına dönük Türk resim sanatı. İstanbul: Türkiye İş Bankası.

Turhan, M. (2015). Kültür değişmeleri. Ankara: Altınordu.

Wallace, R. A. ve Wolf, A. (2012). Çağdaş sosyoloji kuramları. (L. Elburuz, Çev.). İstanbul: Doğu- Batı.

Williams, R. (1977). Culture and society: 1780-1950. Middlesex: Penguin.

Yaman, Z. Y. (1994). Demokrasi ve sanat. Türkiye' de Sanat, (15), 21-29.

Yardımc1, R. (1999). Atatürkçü düşüncede ulusal kimlik bilinci kavramı. Doktora tezi, İstanbul Üniversitesi Atatürk İlkeleri ve İnkılap Tarihi Enstitüsü, İstanbul.

Yeşildal, H. (2012). Toplumsal değişme ve küreselleşme. N. Suğur (Ed.), Sosyolojiye giriş içinde (s. 67-104). Eskişehir: Anadolu Üniversitesi.

Yıldırım, A. ve Şimşek, H. (2006). Sosyal bilimlerde nitel araştırma yöntemleri. Ankara: Seçkin.

Yıldırım, K. (2019). Cumhuriyet döneminde Türkiye çalışma hayatının gelişimi. N. Suğur (Ed.), Türkiye'de toplumsal yapı ve değişim içinde (s. 221-246). Ankara: Nobel.

\section{Yazarların Katkı Oranı Beyanı}

Yazarlar araştırma sürecinde eşit oranda katkı sağlamıştır.

\section{Destek ve Teşekkür Beyanı}

Bu araştırmada herhangi bir kurum, kuruluş ya da kişiden destek alınmamıştır.

\section{Çatışma Beyanı}

Araştırmacının araştırma ile ilgili diğer kişi ve kurumlarla herhangi bir kişisel ve finansal çıkar çatışması yoktur.

\section{Etik Bildirim}

Bu makale, derleme türünde olduğu için etik kurul kararı gerektirmemektedir. 